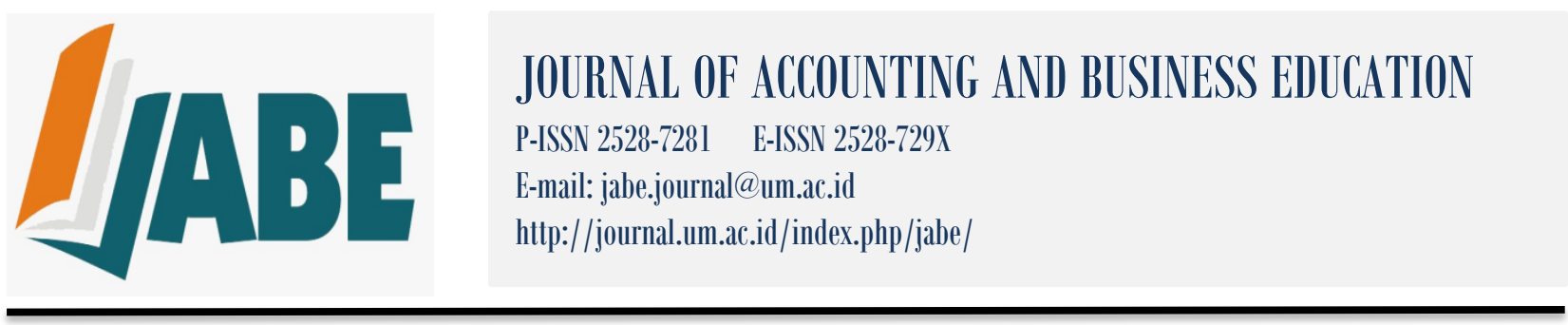

\title{
The Influence of Environmental and Social Performance towards Cumulative Abnormal Return on Listed Companies in Indonesia Stock Exchange
}

\author{
Lilis Nur Indahsari \\ Purweni Widhianningrum \\ Accounting Education Departement, University of PGRI Madiun \\ weni.widhi@gmail.com
}

\begin{abstract}
This research aims to determine the influence of environmental and social performance against the cumulative abnormal return on listed companies in Indonesia stock exchange. The type of this research is quantitative research. The population in this research are all listed companies in Indonesia stock exchange during the period of the year 2012-2015. Sampling techniques in this research using the technique of purposive sampling, so that obtained the number of samples as much as 11 companies. Data analysis techniques in this study using multiple regression analysis. The results of this research showed that the environment and social performance have significant impact on the cumulative abnormal return. This indicates that investors are more concerned about social performance because it's related to the welfare of the community especially employees.
\end{abstract}

Keywords: Environmental performance, social performance, cumulative abnormal return

\section{INTRODUCTION}

The decision of an investor to invest is based on a company's performance appraisal. The purpose of the investors investing the funds is to obtain a high return, so that the stocks of companies that show the best performance that will be in demand by investors (Amalia, Arfan and Shabri, 2014). The same thing is expressed by Tandelilin (2010) that one of the factors that motivate investors to invest is return. Return is an advantage gained by companies, individuals and institutions of the investment policy results that it does (Fahmi, 2013).

A market reacts quickly and accurately to achieve a new equilibrium price that fully reflects the available information, hence the market condition is called an efficient market (Hartono, 2015). While the information will be responded by the market indicated by the return is not normal. Abnormal return is a return that occurs due to an event. The normal return is the supposed return if no event occurs (Hartono, 2015). According to Tandelilin (2010), the return 
can be differentiated into the expected return and actual return. Return of expectation is the level of return anticipated by investors in the future while the actual return is the rate of return that has been obtained by investors. There is no effect of changes in expected return on the actual return of the portfolio. So the determination of the expected return is not necessarily give the actual return to the maximum. This is due to the difference in projected stock prices (Zubir, 2011).

Abnormal return is an indicator to measure the efficiency of a capital market. If the price of an investment instrument has reflected all of the available information then the expected return on a stock price will be equal to the realization return (Silalahi, 2014). To find out the target investor can be achieved, then the portfolio performance needs to be calculated and measured based on portfolio return (Hartono, 2015). While the accumulation of abnormal daily returns during the event period is called cumultive abnormal return (Tandelilin, 2010).

One of the phenomena of corporate strategy that can accommodate the needs and interests of stakeholders is corporate social responsibility (Muid, 2011). Corporate Social Responsibility is an important element in the company's sustainability that includes economic, environmental and social aspects (Rahmani, 2013). The practice of Corporate Social Responsibilty in Indonesia is based on Law Number 40 of Article 74 paragraph (1) of 2007 concerning Limited Liability Company which explains that a company that carries out its business activities in the field and / or related to natural resources is obliged to carry out social and environmental responsibility.

Disclosure of environmental performance as corporate social responsibility can affect financial performance. Because companies that have good environmental performance, indirectly have a good social information so as to increase the value of the company. The view that a company that performs a good environmental performance and good corporate information disclosure is also expected to be a consideration for investors to capitalize (Bahri and Cahyani, 2016).

In addition to environmental performance, there is another performance that needs to be considered also the social performance. Rahmani (2013) states that Corporate social responsibility social dimension is a measurement of corporate social responsibility specifically based on social dimension. The reasons that encourage Deegan's social and environmental disclosure practices (in Ghozali and Chariri, 2007) are, among other things, to comply with the existing requirements of the law, consideration of economic rationality, adhere to reporting in accountability processes, comply with lending requirements, adhere to community expectations, 
on the legitimacy of the company, managing certain stakeholder groups, attracting investment funds, complying with industry requirements, and winning reporting awards.

The results of previous research (Titisari, Suwardi and Setiawan, 2010; Rahmani, 2013; and Haholongan, 2016) show that the environment dimension in CSR disclosure has significant effect on cumulative abnormal return. This proves that companies that perform and disclose CSR dimensions environment in the annual report is considered to have a good image by stakeholders, especially investors so that will be responded positively also by investors through fluctuations in stock prices of companies that increasing from period to period. Thus, the maintenance and preservation of the environment is one factor that becomes the consideration of investors and stakeholders in making investment decisions in investing (Rahmani, 2013).

Other empirical studies (Muid, 2011, Rahmani, 2013 and Sukanto and Widaryanti, 2014) show that social dimension in CSR disclosure has significant effect on cumulative abnormal return. This shows that companies capable of implementing social responsibility around it are considered to be able to control the social environment through the value of investments invested in social activities. The more complete disclosure of corporate social responsibility further improves the company's performance. Company performance increases, it will increase the company profit. Increased profit will encourage the increase of stock return of company (Sukanto and Widaryanti, 2014).

Based on the introduction above, this study aims to determine the influance of economic and social performance to cumulative abnormal return. Hopefully this research will provide benefits and increase knowledge in accounting issues, especially to efforts the awareness, empowerment, and social and environmental transformation. In addition, the results of this study are expected to build public awareness in general and the government in particular to jointly oversee the implementation of CSR and regulations that regulate the implementation of business activities.

The structure of this research is divided into four sections. The beginning of the article presented the background of the occurrence of social environmental problems. The second part will be presented basic theory of this research. The third part, the authors will offer a research methodology to describe the variables and methods of analysis to be studied. The final section will present the results, discussion and research conclusions. 


\section{LITERATUR REVIEW AND HYPOTHESES}

Investment is a commitment to allocate some funds to one or more assets (at the moment) that are expected to be able to provide return (profit) in the future (Susilo, 2009). However, the investment is not only related to returns but also related to risk. Risk is the level of potential losses that arise because the acquisition of expected investment results are not in line with expectations (Fahmi, 2013). The relationship between risk and expectation return is a linear and directional relationship. Because the return is differentiated into the expectation and actual return. Where the expectation return is the level of return anticipated by investors in the future while the actual return is the rate of return that has been obtained by investors. Thus the accumulation of abnormal daily returns during the event period is called cumultive abnormal return (Tandelilin, 2010). Cumultive abnormal return can be defined as the sum of abnormal returns of the previous day in the event period for each of the securities (Hartono, 2015). The same thing is also expressed by Samsul (2015) that cumultive abnormal return is a daily or monthly cumulative of abnormal return from the beginning to the next divided by the number of days or months for each type of stock.

Environmental performance is the company's performance to contribute in preserving the environment (Haholongan, 2016). Because the dimensions of environmental sustainability are closely related to the organization's impact on living and non-living systems, including land, air, water, and ecosystems (GRI.4, 2013). Rahmani (2013) discloses that corporate social responsibility with the environment dimension is a specific measurement based on the environmental dimension of sustainability that affects the impact of the organization on natural living systems including ecosystems, soil, water and air. The results of previous research (Titisari, Suwardi and Setiawan, 2010; Rahmani, 2013; and Haholongan, 2016) show that the environment dimension in CSR disclosure has a significant effect on cumulative abnormal return. Based on the theory and previous research, the hypothesis developed in this study as follows:

$\mathbf{H}_{1}$ : Environmental performance has a positive and significant effect on cumulative abnormal return.

Social performance is a measure of corporate social responsibility specifically based on social dimensions (Rahmani, 2013). Social parameters describe the activities that exist in the company that is intended for social welfare around (Sukanto and Widaryanti, 2014). Social 
performance indicators related to employment practices and workplace, human rights, community or social convenience, and responsibility for products (GRI.4, 2013). The results of previous research (Muid, 2011, Rahmani, 2013 and Sukanto and Widaryanti, 2014) prove that social dimension in CSR disclosure has significant effect on cumulative abnormal return. Based on the theory and previous research, the hypothesis developed in this study as follows:

$\mathbf{H}_{2}$ : Social performance has a positive and significant effect on cumulative abnormal return.

Based on the theoretical framework and research problem, it can be designed a research study describes as following figure:

\section{Figure 1}

\section{Research Design}

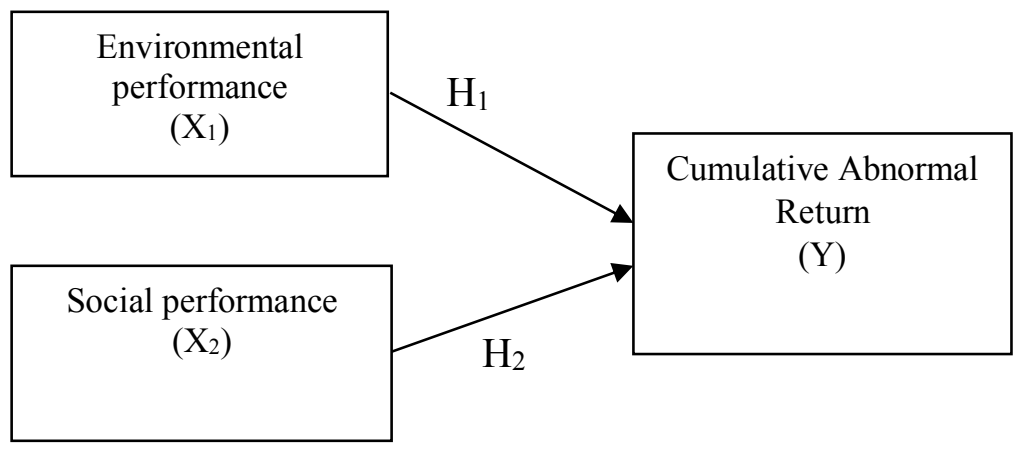

\section{METHODS}

The population in this study are all companies listed on the Indonesia Stock Exchange in 2012-2015. The sample is taken using purposive sampling technique that is using criterion which have been determined by researcher. The criteria used are as follows:

Tabel 1:

Sampling Criteria

\begin{tabular}{llr}
\hline \multicolumn{1}{c}{ Criteria } & Numbers \\
\hline 1. & $\begin{array}{l}\text { Companies listed on the Indonesia Stock Exchange consistently in the research } \\
\text { period of 2012-2015. }\end{array}$ \\
2. The Company publishes the full monthly closing price in the 2012-2015 research & \\
period. & $(1)$ \\
3. & Companies that do not publish consistent and complete sustainability reports in the \\
2012-2015 research period. & $(462)$ \\
Total & 11 \\
\hline
\end{tabular}


Data source in this research is secondary data. Data collection techniques in this study is the documentation of the monthly closing price and susbtainability report obtained by downloading through the official website (www.idx.co.id) and the official website of each sample company. Measurement of the variables used in this study can be explained as follows:

a. Cumulative Abnormal Return (CAR)

Rating of stock price in this study using closing price every month (Hartono, 2015 and Samsul, 2015). While the cumulative abnormal return is calculated by logarithm, to overcome the stock return data is not normally distributed. Thus, stock returns with negative value (decreasing stock price) need to be added value 1 so that logarithm can be used and stock return is positive (Hartono, 2015). The steps in calculating Cumultive Abnormal Return can be formulated as follows:

1. Abnormal Return

$$
\begin{array}{ll}
\mathrm{R}_{\mathrm{it}} & \log \left(\frac{\mathrm{P}_{\mathrm{i}, \mathrm{t}}-\mathrm{P}_{\mathrm{i}, \mathrm{t}-1}}{\mathrm{P}_{\mathrm{i}, \mathrm{t}-1}}\right) \\
\mathrm{E}\left(\mathrm{R}_{\mathrm{it}}\right) & \frac{\mathrm{IHSG}_{\mathrm{t}}-\mathrm{IHSG}_{\mathrm{t}-1}}{\mathrm{IHSG}_{\mathrm{t}-1}} \\
\text { RTN }_{\mathrm{i}, \mathrm{t}} & \mathrm{R}_{\mathrm{it}}-\mathrm{E}\left(\mathrm{R}_{\mathrm{it}}\right)
\end{array}
$$

2. Cumulative Abnormal Return:

$$
\operatorname{ARTN}_{(\mathrm{t} 1, \mathrm{tp}) \mathrm{i}}=\sum_{\mathrm{t}=\mathrm{t} 1}^{\mathrm{tp}} \operatorname{RTN}_{\mathrm{i}, \mathrm{t}}
$$

b. Environmental performance

The disclosure of environmental performance in this study is guided by GRI.4 (2013). The environmental performance indicator consists of 34 indicators. Measurement of environmental performance refers to research Awuy, Sayekti, Purnamawati (2016) and formulated as follows:

$$
\begin{aligned}
\text { EP } & =\frac{\text { The number of corporate environmental performance disclosure items }}{\text { The number of GRI.4 disclosure }} \\
& =\frac{\text { Number of items of corporate environmental performance disclosure }}{34}
\end{aligned}
$$


c. Social performance

Disclosure of social performance in this study is guided by GRI.4 (2013). Social performance indicators consist of 48 indicators with 4 categories, employment practices and comfort work 16 indicators, human rights 12 indicators, community 11 indicators, and responsibility for product 9 indicators. The measurement of social performance refers to the research of Awuy, Sayekti, Purnamawati (2016) and formulated as follows:

$$
\begin{aligned}
\mathrm{SP} & =\frac{\text { The number of corporate social performance disclosure items }}{\text { The number of GRI.4 disclosure }} \\
& =\frac{\text { Number of items of corporate social performance disclosure }}{48}
\end{aligned}
$$

Methods of data analysis in this study using Multiple Linear Regression. The form of empirical model of multiple linear regression in this research are:

$$
\mathrm{Y}=\mathrm{a}+\mathrm{b}_{1} \mathrm{X}_{1}+\mathrm{b}_{2} \mathrm{X}_{2}
$$

Information :

$$
\begin{aligned}
& \mathrm{Y}=\text { Cumulative Abnormal Return, } \\
& \mathrm{X}_{1}=\text { Environmental performance, } \\
& \mathrm{X}_{2}=\text { Social performance, } \\
& \mathrm{a} \text { dan } \mathrm{b}_{1} \text { serta } \mathrm{b}_{2}=\text { constant }
\end{aligned}
$$

\section{RESULT}

\section{Classic Assumption Test}

a. Normality Test

\section{Figure 2:}

\section{Histogram}

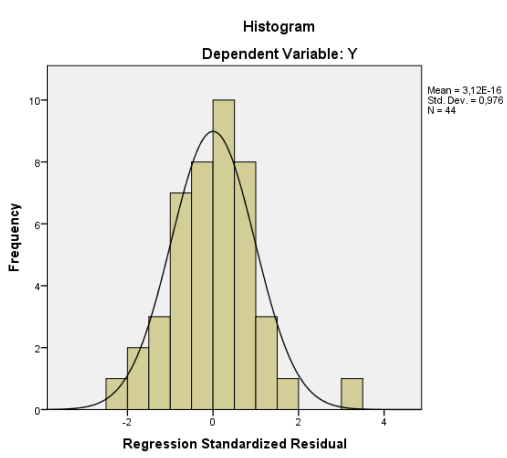




\section{Figure 3:}

\section{Normal Probability Plot}

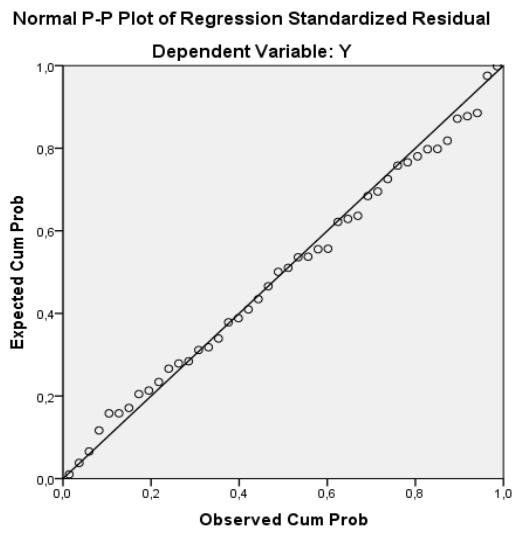

Based on the picture above shows that the histogram graph forms like a bell (curved) so it indicates that the data is normally distributed. While the P-Plot shows the tick-point on the chart where the P-Plot spreads following the diagonal line, thus indicating the data is normally distributed. These two graphs show that the regression model has met the assumption of normality since both graphs are normally distributed.

b. Multicollinearity Test

\section{Tabel 2:}

\section{Multicollinearity Test Result}

\begin{tabular}{|c|c|c|}
\hline \multirow[b]{2}{*}{ Variabel } & \multicolumn{2}{|c|}{ Collinearity Statistics } \\
\hline & Tolerance & VIF \\
\hline $\mathrm{X} 1$ & 0,334 & 2,995 \\
\hline $\mathrm{X} 2$ & 0,334 & 2,995 \\
\hline
\end{tabular}

a. Dependent Variable: Y

Based on table above shows that the VIF value, for environmental performance has a VIF value of $2.995<10$ and a tolerance value of $0.334>0.10$, then there is no multicollinearity. Social performance has VIF value of $2,995<10$ and tolerance value is $0,334>0,10$, hence there is no multicollinearity. 
c. Heteroscedasticity Test

\section{Figure 4:}

\section{Scatterplot}

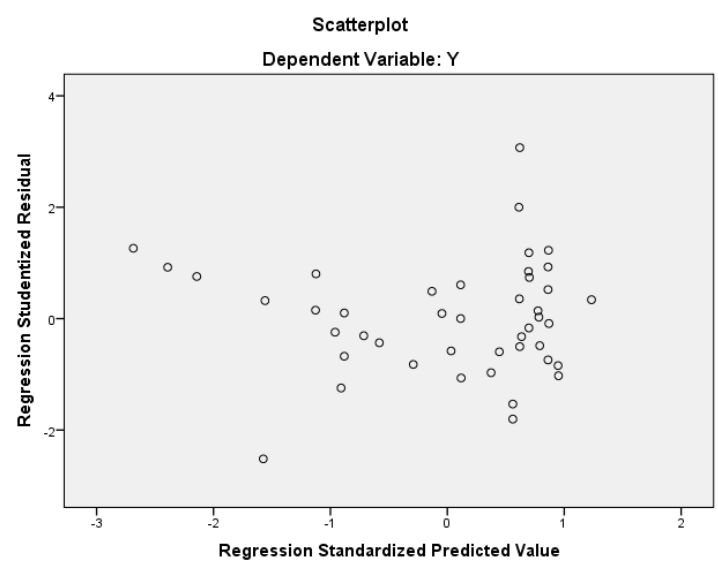

Based on figure 3 above, it shows that the points spread randomly so it can be concluded that there is no heteroscedasticity in linear regression.

d. Autocorrelation Test

\section{Tabel 3:}

Durbin-Watson test result

\begin{tabular}{cccc}
\hline Coeficients of D-W & & & \\
& $\mathrm{d}_{\mathrm{U}}$ & DW & 4- $\mathrm{d}_{\mathrm{U}}$ \\
\hline 1,519 & 1,615 & 1,632 & 2,385
\end{tabular}

Sumber: data diolah, 2017

From table 3 shows that there is a DW value of 1.632. The $\mathrm{dU}$ value for significance 0.05 with $\mathrm{n}=44$ and $\mathrm{k}=2$ is 1.615 and the value is $4-\mathrm{dU}=2,385$. Therefore $\mathrm{DW}$ is between $\mathrm{dU}$ and 4-dU, that is $(1,615<1,632<2,385)$, so it can be concluded there is no autocorrelation in the regression model. 
2. Multiple Regression Analysis

Tabel 4:

Multiple Regression Analysis

\section{Coefficients $^{\mathrm{a}}$}

\begin{tabular}{|c|c|c|c|c|c|}
\hline \multirow[b]{2}{*}{ Model } & \multicolumn{2}{|c|}{$\begin{array}{l}\text { Unstandardized } \\
\text { Coefficients }\end{array}$} & \multirow{2}{*}{$\begin{array}{l}\text { Standardized } \\
\text { Coefficients } \\
\text { Beta }\end{array}$} & \multirow[b]{2}{*}{$\mathrm{t}$} & \multirow[b]{2}{*}{ Sig. } \\
\hline & B & Std. Error & & & \\
\hline $1 \quad$ (Constant) & 2,031 & 0,501 & & 4,055 & 0,000 \\
\hline $\mathrm{X}_{1}$ & $-6,170$ & 1,506 & $-0,914$ & $-4,096$ & 0,000 \\
\hline$X_{2}$ & 4,525 & 1,843 & 0,548 & 2,455 & 0,018 \\
\hline
\end{tabular}

a. Dependent Variable: $\mathrm{Y}$

Based on the above table, then the linear equation can be formulated:

$$
Y=2,031-6,170 X_{1}+4,525 X_{2}
$$

The equation shows that the constant value of 2.031 means that if the company discloses environmental and social performance, then the cumulative abnormal return of the company is 2.031 units. Regression coefficient of environmental performance variable equal to - 6,170 indicate that every increase one unit of environmental performance disclosed by company, hence will decrease cumulative abnormal return value equal to - 6,170 unit. Regression coefficient of social performance variable equal to 4,525 indicate that every increase one unit of social performance expressed by company will add value cumulative abnormal return equal to 4,525 unit.

\section{DISCUSSIONS}

The results of the analysis prove that environmental performance has a negative and significant effect on cumulative abnormal return. Negatively influenced by most companies used as samples in this research is a company whose operational activities are not directly related to natural resources. Of the 11 sample companies only 3 companies consistently meet the criteria of environmental performance. This illustrates that the level of investor awareness of the importance of environmental aspects management is still not maximized. This result is consistent with Friedman's opinion that the company's responsibility is to generate profits as much as possible for shareholders (Untung, 2008). Sutedi (2011) discloses that in achieving favorable returns for shareholders, managers should take account of the constraints that arise in the 
environment in which they operate, including ethical and moral issues, laws, government policies, the environment, social, political and economic. This study is supported by the results of research Rahmani (2013) and Sukanto and Widaryanti (2014) which proves that environmental performance has a negative effect and significant abnormal return. According to Sukanto and Widaryanti (2014) the negative direction indicates that the company's previous operations caused environmental damage, causing the environment dimension in CSR disclosure to be responded not as CSR cost but as the cost of recovery for the damage of the environment which has become its legal obligation.

The results of the analysis prove that social performance has a positive and significant effect on cumulative abnormal return. Positive and significant influence in this study illustrates that the awareness of companies and investors to pay attention to the social aspects associated with the operational activities of the company at this time has begun to increase. In addition, this is due to the consistency of the sample companies against the disclosure of social performance under GRI guidelines.4. Of the 11 sample companies, almost all companies meet the social performance disclosure criteria that should be disclosed in accordance with GRI guidelines.4. It shows that investor awareness related to the management of social performance is getting better. Based on the vision of the company's sample mission, overall it is stated that the company's orientation is the welfare of society. And to make this happen, the investor should be more concerned about social relationships with the community, especially the employees who become the company's assets in its operational activities. The result of this research is supported by research of Muid (2011), Rahmani (2013) and Sukanto and Widaryanti (2014) which proves that social dimension in CSR disclosure have positive and significant effect on CAR. According to Sukanto and Widaryanti (2014), companies capable of implementing social responsibility around it are considered to be able to control the social environment through the value of investments invested in social activities. Suppose the well-being of employees who pay attention will make employees more able to work well and employee loyalty can be maintained. The more complete disclosure of corporate social responsibility (social dimension) further improves the company's performance. Company performance increases, it will increase the company profit. Profit is increasing then it will encourage the increase of stock return company. 


\section{CONCLUSION}

The results of this study indicate that environmental performance has a negative and significant effect on cumulative abnormal return, while social performance has a positive and significant effect on cumulative abnormal return. This shows that investors are more concerned about social performance than environmental performance because social performance is related to the welfare of society which is still a priority company. Based on the results of research conducted, there are several suggestions that can be used as consideration by some parties. For the company, it is expected that the results of this study can provide an overview and raise awareness of the importance of non-financial aspects related to social responsibility to all stakeholders. For investors, social responsibility can be one of the considerations in making investment decisions. As for the next researcher, it is expected to increase the sample, the longer term of research and other indicators related to cumulative abnormal return so that the results obtained can reflect the condition of the company as a whole.

\section{REFERENCES}

Amalia, R. Arfan, M. \& Shabri, M. (2014). Pengaruh Laba, Pengungkapan Corporate Social Responsibility, dan Profitabilitas Terhadap Abnormal Return Saham. Jurnal Akuntansi, 3 (1) pp. 124-132. http://www.unsyiah.ac.id.04.04.17.

Awuy, V.P. Sayekti, Y. \& Purnamawati, I. (2016). Pengaruh Pengungkapan Corporate Social Responsibility (CSR) Terhadap Earnings Response Coefficient (ERC). Jurnal Akuntansi dan Keuangan, 18 (1) pp. 15-26. http:/www.stesie.ac.id.23.02.17.

Bahri, S. \& Cahyani, F.A. (2016). Pengaruh Kinerja Lingkungan Terhadap Corporate Financial Performance Dengan Corporate Social Responsibility Disclosure Sebagai Variabel Intervening. Jurnal Ekononika, 1 (2) pp. 117-142. http://fe.unik-kediri.ac.id.30.08.17.

Fahmi, I. (2013). Pengantar Pasar Modal Panduan Bagi Para Akademisi dan Praktisi Bisnis dalam Memahami Pasar Modal Indonesia. Bandung: Alfabeta.

Ghozali, I \& Chariri, A. (2007). Teori Akuntansi. Semarang: Badan Penerbit Universitas Diponegoro.

Haholongan, R. (2016). Kinerja Lingkungan Dan Kinerja Ekonomi Perusahaan Manufaktur Go Public. Jurnal Ekonomi dan Bisnis, $19 \quad$ (3) pp. 413-424. http://www.uksw.edu.com.09.05.17

Hartono, J. (2015). Studi Peristiwa Menguji Reaksi Pasar Modal Akibat Suatu Peristiwa. Yogyakarta: BPFE-Yogyakarta. 
Hartono, J. (2015). Teori Portofolio dan Analisis Investasi. Yogyakarta: BPFE-Yogyakarta.

Muid, D. (2011). Pengaruh Corporate Social Responsibility Terhadap Stock Return. Fokus Ekonomi, 6 (1) pp. 105-121. http://www.stiepena.ac.id.25.02.17.

Pedoman pelaporan berkelanjutan Global Reporting Initiative (GRI). 2013. (www.globalreporting.org)

Rahmani, A. (2013). Pengaruh Corporate Social Responsibility Terhadap Kinerja Perusahaan. Jurnal Ilmu dan Riset Akuntansi, 2 (4) pp. 1-22. http://www.stiesia.ac.id.10.05.17.

Samsul, M. (2015). Pasar Modal dan Manajemen Portofolio. Jakarta: Penerbit Erlangga.

Silalahi, S.P. (2014). Pengaruh Corporate Social Responsibility (CSR) Disclosure, Beta dan Price To Book Value (PBV) Terhadap Earnings Response Coefficient (ERC) Pada Perusahaan Sektor Manufaktur yang Terdaftar di Bursa Efek Indonesia. Jurnal Ekonomi, 22 (1) pp. 1-14. https://media.neliti.com.30.08.17.

Sukanto, E. \& Widaryanti. (2014). Pengaruh Pengungkapan Corporate Social Responsibility Terhadap Stock Return Pada Perusahaan yang Berkaitan dengan Lingkungan yang Listing Di Bursa Efek Indonesia. Fokus Ekonomi, 9 (2) pp. 34-42. http://www.stiepena.ac.id.09.05.17.

Sutedi, A. (2012). Good Corporate Governance. Jakarta: Sinar Grafika.

Tandelilin, E. (2010). Portofolio dan Investasi Teori dan Aplikasi. Yogyakarta: Kanisius.

Titisari K.H. Suwardi E. \& Setiawan, D. (2010). Corporate Social Responsibility (CSR) dan Kinerja Perusahaan. SNA XIII: Simposium Nasional Indonesia. http://www.wordpress.com.25.02.17.

Undang-undang Republik Indonesia Nomor 40 Tahun 2007 tentang Perseroan Terbatas. http://www.hukumonline.com.25-02.2017.

Untung, H.B. (2008). Corporate Social Responsibility. Jakarta: Sinar Grafika.

Zubir, Z. (2011). Manajemen Portofolio Penerapan Dalam Investasi Saham. Jakarta: Salemba Empat. 